\title{
The Risk Analysis of Andalas University Hospital Construction Project
}

\author{
Zaidir $^{1 *}$, Melani Novia Putri², Alizar Hasan² \\ ${ }^{1}$ Andalas University, Department of Civil Engineering, Padang 25163, Indonesia. \\ ${ }^{2}$ Andalas University, Department of Industrial Engineering, Padang 25163, Indonesia
}

\begin{abstract}
Construction project activities have various risks during their implementation. Every work item on the project has different levels of risk and can affect the project so that it will have an impact on increasing cost and time of project completion. PT. Adhi Karya Tbk is carrying out the project of Andalas University Hospital, where in its implementation there will be many possibilities of risks that will occur. Therefore, it is necessary to identify and analyze the variables of risks that may occur as well as proposing appropriate risk mitigation measures for minimize the potential risks. Risk identification and risk analysis were done using Risk Breakdown Structure (RBS) and Analytic Hierarchy Process (AHP) method respectively. Based on data compilation, variables of risk are grouped in 4 types, namely risk of engineering consist of 8 variables, risk of production consist of 5 variables, risk of construction consist of 9 variables and risk of financial consist of 2 variable, with total of risk are 24 variables. Risk analysis with AHP method is obtained 5 (five) risk priority based on the highest value on each risk type. The five priority risks were a risks of increasing of material prices (extreme), a risk of increasing of procurement costs (high), workplace accidents risk in the project area (medium), mistaken translating the DED to shop drawing (medium) and a quality of goods and services produced by vendors not meet the specifications in contract (medium). To reduce the possibility and impact the risks posed mitigation measures for the risk priority highest were proposed.
\end{abstract}

\section{Introduction}

The construction project activities have a risk in their implementation. Each item of work has a different level of risk, depending on its activity. Risk is defined the possibility that something bad or unpleasant will happen. The risks in the construction project however could not be eliminated, but could be reduced or transferred from one party to another. When the risk occurs, it will impact on the disruption of overall project performance so it can cause additional costs, time, and quality of work.

Research of Sandyafitri and Kurniawan [1-2], concluded that implementation of risk management on a project will be able to: 1). reduce delays time of execution of work and increase of project cost, 2). known risk with low, medium and high levels so that the parties involved in the project can anticipate and mitigate to reduce the impact that will caused by such risks, 3). determined risk category with high risk level and medium risk, so that risk can be anticipated by top management with how to prevent the source of the risk.

The research purposes are: a). to identify possible risks on the implementation of Andalas University

\footnotetext{
*Corresponding author: zaidir@eng.unand.ac.id
}

Hospital construction project with Risk Breakdown Structure (RBS) approach, b). to determine a risk weightof each risk variable with Analytic Hierarchy Process (AHP) approach, c). to determine a risk category for each priority risk based on risk assessment matrix and d). to formulate mitigation actions to risk priorities in order the risks are not recurring and the rate of occurrence of risk is reduced.

\section{Literature Reviews}

Project construction is a series of activities to build a civil construction such as buildings, bridges or other infrastructures. There are various activities within the construction project where the project activity is a temporary within a limited period of time with the allocation certain funding to achieve a target has been decided. With so many activities and parties involved in the implementation of construction projects, can cause many problems of a nature complex [3]. Figure 1 shows the parties involved in construction projects [4]. 


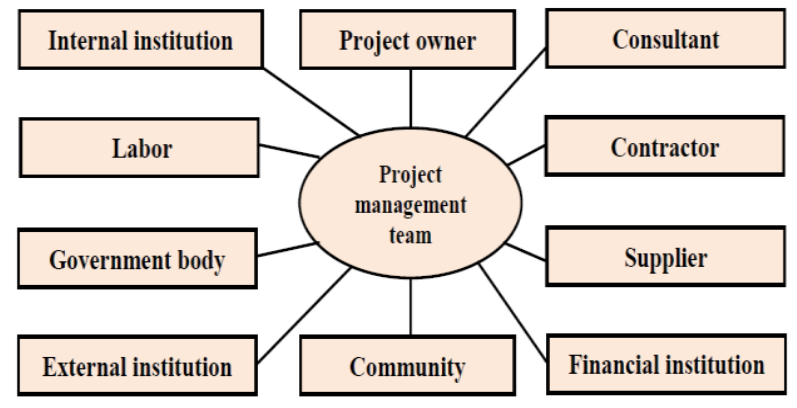

Fig. 1. Parties involved in construction projects

\subsection{Risks in Construction Projects}

Risks in a construction project are defined as an explanation of unfavorable consequences, both financially and physically as a result of decisions taken or due to environmental conditions at the site of an activity. The risks in a construction project area something that can't be eliminated, but can be minimized their impact.Risk can have an indirect impact on project implementation schedule. The risk categories in construction projects can be grouped in external risks and site conditions, economic and financial risks, technical and contractual risks and managerial risk [5], as shown in Table 1.

Table 1. The risk categories in construction projects

\begin{tabular}{|c|c|c|}
\hline $\begin{array}{c}\text { Level } 1 \\
\text { The } \\
\text { importance } \\
\text { of each risk } \\
\text { factor }\end{array}$ & $\begin{array}{l}\text { Level } 2 \\
\text { Major } \\
\text { risks }\end{array}$ & $\begin{array}{c}\text { Level } 3 \\
\text { Risk factors }\end{array}$ \\
\hline \multirow{16}{*}{$\begin{array}{l}\text { Relative } \\
\text { importance } \\
\text { of each } \\
\text { risk factor }\end{array}$} & \multirow{4}{*}{$\begin{array}{l}\text { External } \\
\text { and site } \\
\text { condition } \\
\text { risks }\end{array}$} & $\begin{array}{l}\text { Unforeseen site ground } \\
\text { condition }\end{array}$ \\
\hline & & Weather condition \\
\hline & & $\begin{array}{l}\text { Difficult in obtaining } \\
\text { permits and ordinances }\end{array}$ \\
\hline & & $\begin{array}{l}\text { Changes in government } \\
\text { actions }\end{array}$ \\
\hline & \multirow{4}{*}{$\begin{array}{l}\text { Economic } \\
\text { and } \\
\text { financial } \\
\text { risks }\end{array}$} & $\begin{array}{l}\text { High inflation/increase } \\
\text { price }\end{array}$ \\
\hline & & $\begin{array}{l}\text { Delayed payments on } \\
\text { contract }\end{array}$ \\
\hline & & High interest rate \\
\hline & & Poor cost control \\
\hline & \multirow{4}{*}{$\begin{array}{l}\text { Technical } \\
\text { and } \\
\text { contractual } \\
\text { risks }\end{array}$} & Defective design \\
\hline & & Design change by owner \\
\hline & & $\begin{array}{l}\text { Inadequately compensated } \\
\text { variation order }\end{array}$ \\
\hline & & $\begin{array}{l}\text { Delay in providing detail } \\
\text { drawing }\end{array}$ \\
\hline & \multirow[t]{4}{*}{$\begin{array}{l}\text { Managerial } \\
\text { risks }\end{array}$} & $\begin{array}{l}\text { Defective construction } \\
\text { work }\end{array}$ \\
\hline & & $\begin{array}{l}\text { Low labor and equipment } \\
\text { productivity }\end{array}$ \\
\hline & & $\begin{array}{l}\text { Inadequate project } \\
\text { program }\end{array}$ \\
\hline & & $\begin{array}{l}\text { Problems with availability } \\
\text { of labor, material and } \\
\text { equipment }\end{array}$ \\
\hline
\end{tabular}

\subsection{Risk Breakdown Structure Method}

The Risk Breakdown Structure (RBS) method is mainly used to do categories each risk. RBS is a grouping of risks in a composition hierarchical organizational risk that is logical, systematic, and structured according to the structure organization or project. The goal of RBS implementation is the clarity of risk stakeholders and increased understanding of organizational or project risks within the context of that framework logical and systematic [6].

\subsection{Analytic Hierarchy Process (AHP)}

Analytic Hierarchy Process (AHP) is one of the deep methods to support decision making developed by Thomas L. Saaty [7]. This decision support model describes multifactor problem or complex multicriteria becomes a hierarchy. The hierarchy is defined as a representation of a complex problem in a multilevel structure. With a hierarchy, a complex problem can be brakedown into groups which is then organized into a hierarchical form so that the problem will appear more structured and systematic [5]. The steps of the AHP method are as follows:

(1) Arrange a hierarchy of problems. Problems to be solved are described into its elements, such as criteria and alternatives which are then compiled into a hierarchical structure.

(2) Assessment criteria and alternatives. The criteria and alternatives assessment is done by pairing comparisons with an assessment of the importance of two elements at a certain level in relation to the above level.

(3) Combine the opinions of respondents. Combining the opinions of respondents is done for each matrix of comparison of each respondent so that obtained matrix of comparison of new pairs which is combined of answer all respondents.

(4) Determination of priority matrix. The paired comparison assessment result that has been done then presented in the form of comparison matrix.

(5) Consistency test. Consistency test is used to determine the level of consistency of the risk weighted value obtained. Results of evaluation are received if the consistency ratio $(\mathrm{CR}) \leq 0.1$.

\section{Results and Discussions}

\subsection{Risk Variable Identification}

The identification of risk variables is obtained from the discussion and deep interview with PT. Adhi Karya Tbk Project Production Manager (PPM). Identification of risk variables were also obtained from literature such as journals, prior research, text books and so on. Identification of risk variables is performed for possible risks occurred on the implementation of the construction project of Andalas University Hospital. With the development stages of Risk Breakdown Structure (RBS) through bottom up approach, the result of identifying the 
risk variable in the project construction of Andalas University Hospital were shown in Table 2.

Table 2. Identified Risk Variables on the Andalas University Hospital Project

\begin{tabular}{|c|c|c|c|}
\hline $\begin{array}{l}\text { Risk } \\
\text { type }\end{array}$ & $\begin{array}{l}\text { Risk } \\
\text { Code }\end{array}$ & Risk Variables & Source \\
\hline \multirow[t]{8}{*}{$\begin{array}{l}\text { Engi- } \\
\text { neering }\end{array}$} & R01 & $\begin{array}{l}\text { Permits process take } \\
\text { time }\end{array}$ & $\begin{array}{l}\text { PT.Adhi } \\
\text { Karya Tbk }\end{array}$ \\
\hline & R02 & $\begin{array}{l}\text { Access to location is } \\
\text { not smooth }\end{array}$ & $\begin{array}{l}\text { PT.Adhi } \\
\text { Karya Tbk }\end{array}$ \\
\hline & R03 & $\begin{array}{l}\text { Project location is not } \\
\text { yet free }\end{array}$ & $\begin{array}{l}\text { PT.Adhi } \\
\text { Karya Tbk }\end{array}$ \\
\hline & R04 & $\begin{array}{l}\text { Field conditions are } \\
\text { not in accordance with } \\
\text { the DED data }\end{array}$ & $\begin{array}{l}\text { PT.Adhi } \\
\text { Karya Tbk }\end{array}$ \\
\hline & R05 & $\begin{array}{l}\text { Calculation of } \\
\text { production capacity } \\
\text { not in accordance with } \\
\text { the planned }\end{array}$ & $\begin{array}{l}\text { PT.Adhi } \\
\text { Karya Tbk }\end{array}$ \\
\hline & R06 & $\begin{array}{l}\text { Mistaken translating } \\
\text { DED to shop drawing }\end{array}$ & $\begin{array}{l}\text { PT.Adhi } \\
\text { Karya Tbk }\end{array}$ \\
\hline & R07 & $\begin{array}{l}\text { Price estimates } \\
\text { (wages, material and } \\
\text { equipments) do not } \\
\text { match the field } \\
\text { conditions }\end{array}$ & $\begin{array}{l}\text { PT.Adhi } \\
\text { Karya Tbk }\end{array}$ \\
\hline & R08 & $\begin{array}{l}\text { Design changes by } \\
\text { owner }\end{array}$ & $\begin{array}{l}\text { Ratnaningsih } \\
\text { et.al. (2014) }\end{array}$ \\
\hline \multirow[t]{5}{*}{$\begin{array}{l}\text { Product- } \\
\text { ion }\end{array}$} & R09 & $\begin{array}{l}\text { Quality of goods and } \\
\text { services produced by } \\
\text { vendors not meet the } \\
\text { specifications }\end{array}$ & $\begin{array}{l}\text { PT.Adhi } \\
\text { Karya Tbk }\end{array}$ \\
\hline & R10 & $\begin{array}{l}\text { Materials used less } \\
\text { than required }\end{array}$ & $\begin{array}{l}\text { Ismael and } \\
\text { Junaidi } \\
\text { (2014) }\end{array}$ \\
\hline & R11 & $\begin{array}{l}\text { The accumulation of } \\
\text { material }\end{array}$ & $\begin{array}{l}\text { Ismael and } \\
\text { Junaidi } \\
\text { (2014) }\end{array}$ \\
\hline & R12 & $\begin{array}{l}\text { Inaccurate time of } \\
\text { ordering of materials }\end{array}$ & $\begin{array}{l}\text { Ismael and } \\
\text { Junaidi } \\
\text { (2014) }\end{array}$ \\
\hline & R13 & $\begin{array}{l}\text { Shortage of } \\
\text { construction materials }\end{array}$ & $\begin{array}{ll}\text { Ismael and } \\
\text { Junaidi } \\
\text { (2014) }\end{array}$ \\
\hline \multirow[t]{9}{*}{$\begin{array}{l}\text { Cons- } \\
\text { truction }\end{array}$} & R14 & $\begin{array}{l}\text { Delay of construction } \\
\text { activity }\end{array}$ & $\begin{array}{l}\text { PT.Adhi } \\
\text { Karya Tbk }\end{array}$ \\
\hline & R15 & $\begin{array}{l}\text { Mistaken in job } \\
\text { execution }\end{array}$ & $\begin{array}{l}\text { PT.Adhi } \\
\text { Karya Tbk }\end{array}$ \\
\hline & R16 & $\begin{array}{l}\text { Accident in the project } \\
\text { area }\end{array}$ & $\begin{array}{l}\text { PT.Adhi } \\
\text { Karya Tbk }\end{array}$ \\
\hline & R17 & $\begin{array}{l}\text { Mistaken determines } \\
\text { the job stages }\end{array}$ & $\begin{array}{l}\text { PT.Adhi } \\
\text { Karya Tbk }\end{array}$ \\
\hline & R18 & $\begin{array}{l}\text { Mistaken in } \\
\text { construction method }\end{array}$ & $\begin{array}{l}\text { PT.Adhi } \\
\text { Karya Tbk }\end{array}$ \\
\hline & R19 & $\begin{array}{l}\text { Mistaken in determine } \\
\text { equipment and } \\
\text { supporting materials }\end{array}$ & $\begin{array}{l}\text { PT.Adhi } \\
\text { Karya Tbk }\end{array}$ \\
\hline & R20 & $\begin{array}{l}\text { Weather disturbances } \\
\text { that cause project } \\
\text { delays }\end{array}$ & $\begin{array}{l}\text { Ismael } \\
(2013)\end{array}$ \\
\hline & R21 & Shortage of labor & $\begin{array}{l}\text { PT.Adhi } \\
\text { Karya Tbk }\end{array}$ \\
\hline & R22 & $\begin{array}{l}\text { Project management is } \\
\text { less competent }\end{array}$ & $\begin{array}{l}\begin{array}{l}\text { Ismael and } \\
\text { Junaidi } \\
\text { (2014) }\end{array} \\
\end{array}$ \\
\hline
\end{tabular}

\begin{tabular}{|l|l|l|l|}
\hline $\begin{array}{l}\text { Finan- } \\
\text { cial }\end{array}$ & R23 & $\begin{array}{l}\text { Additional } \\
\text { procurement costs }\end{array}$ & $\begin{array}{l}\text { PT.Adhi } \\
\text { Karya Tbk }\end{array}$ \\
\cline { 2 - 4 } & R24 & $\begin{array}{l}\text { Increase in building } \\
\text { materials prices }\end{array}$ & $\begin{array}{l}\text { Ismael and } \\
\text { Junaidi } \\
(2014)\end{array}$ \\
\hline
\end{tabular}

From the Table 2, it have 24 (twenty four) risk variables identified on the implementation of the University Andalas hospital project. Each identified risk variables are grouped by type. There are 4 (four) types or risk, namely engineering, production, construction, and financial risks. Risk analysis is done by using Analytic Hierarchy Process approach (AHP). The AHP approach was used to perform inter-pair comparisons risk variables in each type of risk. Through paired comparison analysis, we found the most influential risk weight to the project. Assessment was conducted by 3 (three) experts by filling out the questionnaire.

\subsection{Risk Analysis}

Risk analysis is performed using AHP approach. AHP approach is used to perform pair-wise comparisons between risk variables in each type of risk. By paired comparison analysis it will get the most influential risk weight. After obtained pair-wise comparison matrix, then done normalization result of matrix of pair-wise comparison to get weight value at each variable of risk. Recapitulation of risk weight values for each risk variables are shown in Table 3, 4, 5 and Table 6.

Based on the normalization of comparison matrix on each risk variable, the highest weight was obtained for each risk variable. In the engineering risk variables, the risk that has a highest weight value is the risk of mistaken translating DED to shop drawing (R06) with a weight value of 0.26 . In the production risk variables, a highest value of weight is a quality of goods and services produced by vendors not meet the specifications (R09) with weight value of 0.45 . For construction risk variables, a highest value is an accident in the project area (R16) with weight value of 0.19 , while for the financial risks a both risk of additional procurement costs (R23) and increase in building material prices (R24) have a same weight value of 0.50 .

Table 3. Weight Assessment of Engineering Risk Variables

\begin{tabular}{|l|l|l|l|}
\hline No. & $\begin{array}{l}\text { Risk } \\
\text { Code }\end{array}$ & Potential Risk Priority & $\begin{array}{l}\text { Weight } \\
\text { value }\end{array}$ \\
\hline 1 & R01 & Permits process take time & 0.04 \\
\hline 2 & R02 & Access to location is not smooth & 0.06 \\
\hline 3 & R03 & Project location is not yet free & 0.18 \\
\hline 4 & R04 & $\begin{array}{l}\text { Field conditions are not in } \\
\text { accordance with the DED data }\end{array}$ & 0.17 \\
\hline 5 & R05 & $\begin{array}{l}\text { Calculation of production } \\
\text { capacity not in accordance with } \\
\text { the planned }\end{array}$ & 0.11 \\
\hline 6 & R06 & $\begin{array}{l}\text { Mistaken translating DED to } \\
\text { shop drawing }\end{array}$ & 0.26 \\
\hline 7 & R07 & $\begin{array}{l}\text { Price estimates (wages, material } \\
\text { and equipments) do not match } \\
\text { the field conditions }\end{array}$ & 0.14 \\
\hline 8 & R08 & \begin{tabular}{l} 
Design changes by owner \\
\hline
\end{tabular} \\
\hline
\end{tabular}


Table 4. Weight Assessment of Production Risk Variables

\begin{tabular}{|l|l|l|l|}
\hline No. & $\begin{array}{l}\text { Risk } \\
\text { Code }\end{array}$ & \multicolumn{3}{|l|}{ Potential Risk Priority } & $\begin{array}{l}\text { Weight } \\
\text { value }\end{array}$ \\
\hline 1 & R09 & $\begin{array}{l}\text { Quality of goods and } \\
\text { services produced by } \\
\text { vendors not meet the } \\
\text { specifications }\end{array}$ & 0.45 \\
\hline 2 & R10 & $\begin{array}{l}\text { Materials used less than } \\
\text { required }\end{array}$ & 0.18 \\
\hline 3 & R11 & $\begin{array}{l}\text { The accumulation of } \\
\text { material }\end{array}$ & 0.08 \\
\hline 4 & R12 & $\begin{array}{l}\text { Inaccurate time of ordering } \\
\text { of materials }\end{array}$ & 0.14 \\
\hline 5 & R13 & $\begin{array}{l}\text { Shortage of construction } \\
\text { materials }\end{array}$ & 0.16 \\
\hline
\end{tabular}

Table 5. Weight Assessment of Construction Risk Variables

\begin{tabular}{|c|c|c|c|}
\hline No. & $\begin{array}{l}\text { Risk } \\
\text { Code }\end{array}$ & Potential Risk Priority & $\begin{array}{l}\text { Weight } \\
\text { value }\end{array}$ \\
\hline 1 & R14 & Delay of construction activity & 0.04 \\
\hline 2 & R15 & Mistaken in job execution & 0.13 \\
\hline 3 & R16 & Accident in the project area & 0.19 \\
\hline 4 & R17 & $\begin{array}{l}\text { Mistaken determines the job } \\
\text { stages }\end{array}$ & 0.13 \\
\hline 5 & R18 & $\begin{array}{l}\text { Mistaken in construction } \\
\text { method }\end{array}$ & 0.14 \\
\hline 6 & R19 & $\begin{array}{lcr}\text { Mistaken } & \text { in } & \text { determine } \\
\text { equipment } & \text { and } & \text { supporting } \\
\text { materials } & & \\
\end{array}$ & 0.11 \\
\hline 7 & R20 & $\begin{array}{l}\text { Weather disturbances that cause } \\
\text { project delays }\end{array}$ & 0.07 \\
\hline 8 & R21 & Shortage of labor & 0.05 \\
\hline 9 & R22 & $\begin{array}{l}\text { Project management is less } \\
\text { competent }\end{array}$ & 0.13 \\
\hline
\end{tabular}

Table 6. Weight Assessment of Financial Risk Variables

\begin{tabular}{|l|l|l|l|}
\hline No. & $\begin{array}{l}\text { Risk } \\
\text { Code }\end{array}$ & Potential Risk Priority & $\begin{array}{l}\text { Weight } \\
\text { value }\end{array}$ \\
\hline 1 & R23 & Additional procurement costs & 0.50 \\
\hline 2 & R24 & $\begin{array}{l}\text { Increase in building materials } \\
\text { prices }\end{array}$ & 0.50 \\
\hline
\end{tabular}

\subsection{Risk Assessment and Category}

Based on the value of the consistency ratio obtained in each risk variable, then a weight of each risk variable is acceptable because it has a ratio value consistency $\leq 0.1$. The final results of risk that has priority weight the highest in each type of risk can be seen in Table 7. Once obtained potential risk priority, then performed the risk assessment of the potential risk matrix that priority has been obtained.

The value of priority risk level is calculated by multiplying the value of the possibility of risk with the impacts. The average values and risk level of the expert judgments on the potential risk variables can be seen in Table 8. The highest risk level is the rise in the price of building materials (R24) with a risk level of 20.
Based on the risk level assessment of the potential risk priority, the risk can be categorized into the risk matrix shown in Table 9. After the risk assessment matrix is obtained, the risk is then grouped into risk category based on the value of the risk level obtained. Recapitulation of risk assessment matrix results can be seen in Table 10. Based on the risk assessment matrix obtained, there is an area level for the five identified risk priorities.

Table 7. Potential Risk Priority and Weight Value

\begin{tabular}{|l|l|l|l|l|}
\hline No. & Risk Type & $\begin{array}{l}\text { Risk } \\
\text { Code }\end{array}$ & $\begin{array}{l}\text { Potential Risk } \\
\text { Priority }\end{array}$ & $\begin{array}{l}\text { Weight } \\
\text { value }\end{array}$ \\
\hline 1 & Engineering & R06 & $\begin{array}{l}\text { Mistaken } \\
\text { translating DED } \\
\text { to shop drawing }\end{array}$ & 0,26 \\
\hline 2 & Production & R09 & $\begin{array}{l}\text { Quality of goods } \\
\text { and services } \\
\text { produced by } \\
\text { vendors not meet } \\
\text { the } \\
\text { specifications }\end{array}$ & 0,45 \\
\hline 3 & Construction & R16 & $\begin{array}{l}\text { Accident in the } \\
\text { project area }\end{array}$ & 0,19 \\
\hline 4 & Financial & R23 & $\begin{array}{l}\text { Additional } \\
\text { procurement } \\
\text { costs }\end{array}$ & 0,50 \\
\hline 5 & Financial & R24 & $\begin{array}{l}\text { Increase } \\
\text { building } \\
\text { materials prices }\end{array}$ & 0,50 \\
\hline
\end{tabular}

Table 8. Potential Risk and Risk Levels

\begin{tabular}{|c|c|c|c|c|c|}
\hline \multirow[t]{2}{*}{$\begin{array}{l}\text { No } \\
\text {. }\end{array}$} & \multirow{2}{*}{$\begin{array}{l}\text { Risk } \\
\text { Cod } \\
\text { e }\end{array}$} & \multirow{2}{*}{$\begin{array}{l}\text { Potential } \\
\text { Risk } \\
\text { Priority }\end{array}$} & $\begin{array}{l}\text { Average } \\
\text { opinion }\end{array}$ & experts & \multirow{2}{*}{$\begin{array}{l}\text { Risk } \\
\text { level } \\
\text { s }\end{array}$} \\
\hline & & & $\begin{array}{l}\text { Possibilit } \\
\text { y }\end{array}$ & $\begin{array}{l}\text { Impact } \\
\mathrm{s}\end{array}$ & \\
\hline 1 & R06 & $\begin{array}{l}\text { Mistaken } \\
\text { translating } \\
\text { DED to shop } \\
\text { drawing } \\
\end{array}$ & 4,00 & 2,00 & 8,00 \\
\hline 2 & R09 & $\begin{array}{l}\text { Quality of } \\
\text { goods and } \\
\text { services } \\
\text { produced by } \\
\text { vendors not } \\
\text { meet the } \\
\text { specificatio } \\
\text { ns }\end{array}$ & 3,00 & 2,00 & 6,00 \\
\hline 3 & R16 & $\begin{array}{l}\text { Accident in } \\
\text { the project } \\
\text { area }\end{array}$ & 3,00 & 3,00 & 9,00 \\
\hline 4 & R23 & $\begin{array}{l}\text { Additional } \\
\text { procurement } \\
\text { costs }\end{array}$ & 4,00 & 3,00 & $\begin{array}{l}12,0 \\
0\end{array}$ \\
\hline 5 & R24 & $\begin{array}{l}\text { Increase in } \\
\text { building } \\
\text { materials } \\
\text { prices }\end{array}$ & 5,00 & 4,00 & $\begin{array}{l}20,0 \\
0\end{array}$ \\
\hline
\end{tabular}

There is one risk variable in the extreme and high category which are the increase of building material price (R24) and the additional procurement costs (R23), and three risk variables that are in the medium category namely the mistaken translating DED to shop drawing (R06), the quality of goods and services produced by 
vendors not meet the specifications (R09), and an accident in the project area (R16).

Table 9. Risk Assessment Matrix

\begin{tabular}{|l|l|l|l|l|l|}
\hline \multirow{2}{*}{ Possibility } & \multicolumn{4}{|l|}{ Impacts } & \multicolumn{4}{l|}{} \\
\cline { 2 - 6 } & 1 & 2 & 3 & 4 & 5 \\
\hline 5 & & & & R24 & \\
\hline 4 & & R06 & R23 & & \\
\hline 3 & & R09 & R16 & & \\
\hline 2 & & & & & \\
\hline 1 & & & & & \\
\hline
\end{tabular}

Table 10. Risk Assessment Matrix Recapitulation

\begin{tabular}{|l|l|ll|}
\hline Color code & Risk category & Risk code \\
\hline $\mathrm{TR} \geq 20$ & Extreme & R24 & \\
\hline $10 \leq \mathrm{TR}<20$ & High & R23 & \\
\hline $5 \leq \mathrm{TR}<10$ & Medium & $\begin{array}{l}\text { R06, } \\
\text { R16 }\end{array}$ & \\
\hline $0 \leq \mathrm{TR}<5$ & Low & - & \\
\hline
\end{tabular}

Table 11. Causes and Impacts of Risk Priorities

\begin{tabular}{|c|c|c|c|}
\hline $\begin{array}{l}\text { Risk } \\
\text { Code }\end{array}$ & $\begin{array}{l}\text { Potential } \\
\text { risk priority }\end{array}$ & Causes & Impacts \\
\hline R06 & $\begin{array}{l}\text { Mistaken } \\
\text { translating } \\
\text { DED to shop } \\
\text { drawing }\end{array}$ & $\begin{array}{l}\text { Drawing engineer } \\
\text { is less skilled. }\end{array}$ & Reworks \\
\hline R09 & $\begin{array}{l}\text { Quality of } \\
\text { goods and } \\
\text { services } \\
\text { produced by } \\
\text { vendors not } \\
\text { meet the } \\
\text { specifications }\end{array}$ & $\begin{array}{l}\text { - Vendors pay no } \\
\text { attention to } \\
\text { material to } \\
\text { specifications. } \\
\text { - Vendor } \\
\text { cheating }\end{array}$ & Job delays \\
\hline R16 & $\begin{array}{l}\text { Accident in } \\
\text { the project } \\
\text { area }\end{array}$ & $\begin{array}{l}\text { - Workers are not } \\
\text { careful } \\
\text { - Workers do not } \\
\text { care about safety. } \\
\text { - Contractors do } \\
\text { not care about the } \\
\text { Personal } \\
\text { Protective } \\
\text { Equipment } \\
\text { (PPE/APD) }\end{array}$ & $\begin{array}{l}\text { - Decrease } \\
\text { of } \\
\text { company } \\
\text { performance } \\
\text {-The } \\
\text { insurance } \\
\text { costs to an } \\
\text { accident } \\
\text { workers. }\end{array}$ \\
\hline R23 & $\begin{array}{l}\text { Additional } \\
\text { procurement } \\
\text { costs }\end{array}$ & $\begin{array}{l}\text { Less careful in } \\
\text { market surveys } \\
\text { during } \\
\text { procurement } \\
\text { process. }\end{array}$ & $\begin{array}{l}\text { Increase of } \\
\text { project costs }\end{array}$ \\
\hline R24 & $\begin{array}{l}\text { Increase in } \\
\text { building } \\
\text { materials } \\
\text { prices }\end{array}$ & $\begin{array}{l}\text { - Inflation } \\
\text { - Lack of } \\
\text { materials stock }\end{array}$ & $\begin{array}{l}\text { Increase of } \\
\text { project costs }\end{array}$ \\
\hline
\end{tabular}

\subsection{Evaluation and Treatment of Risks}

Risk evaluation is the process of determining the risk treatment according to the level risks that have been obtained. This risk evaluation can be used in help decision making based on risk analysis. Risk evaluation is used for strengthens the results of expert judgment on identified risks. Based on risk analysis conducted, there are 5 (five) potential risk priorities. From these five priority risks have causes and impacts. The causes and impacts of these five risk priorities can be seen in Table 11. Based on the known causes and impacts of the risk, mitigation measures can be taken on each of these risk priorities. Risk treatment is conducted to reduce the possibility of risk occurrence and risk impact. Each risk variable has different risk treatment depending on the level of risk. Figure 2 illustrates the risk treatment map of each risk priority.

Table 12. Mitigation Measures at Potential Risk Priority

\begin{tabular}{|c|c|c|c|}
\hline $\begin{array}{l}\text { Risk } \\
\text { Code }\end{array}$ & $\begin{array}{l}\text { Risk } \\
\text { Variable }\end{array}$ & $\begin{array}{l}\text { Risk } \\
\text { Category }\end{array}$ & Mitigation \\
\hline R06 & $\begin{array}{l}\text { Mistaken } \\
\text { translating } \\
\text { DED to shop } \\
\text { drawing }\end{array}$ & Medium & $\begin{array}{l}\text { - Make corrections } \\
\text { to drawings design } \\
\text { Beforetranslating } \\
\text { them to shop } \\
\text { drawings. } \\
\text { - Selecting an } \\
\text { expert drawing } \\
\text { engineer }\end{array}$ \\
\hline R09 & $\begin{array}{l}\text { Quality of } \\
\text { goods and } \\
\text { services } \\
\text { produced by } \\
\text { vendors not } \\
\text { meet the } \\
\text { specifications }\end{array}$ & Medium & $\begin{array}{l}\text { - Goods and } \\
\text { services are } \\
\text { returned to the } \\
\text { vendor. } \\
\text { - Selecting a } \\
\text { competent and } \\
\text { qualified } \\
\text { vendor. }\end{array}$ \\
\hline R16 & $\begin{array}{l}\text { Accident in } \\
\text { the project } \\
\text { area }\end{array}$ & Medium & $\begin{array}{l}\text { - Detect as early as } \\
\text { possible potential } \\
\text { risks } \\
\text { in the project. } \\
\text { - Use a personal } \\
\text { protective } \\
\text { equipment } \\
\text { (APD/PPE). } \\
\text { - Conducting } \\
\text { socialization and } \\
\text { safety } \\
\text { instruction before } \\
\text { thework begins to } \\
\text { workers }\end{array}$ \\
\hline $\mathrm{R} 23$ & $\begin{array}{l}\text { Additional } \\
\text { procurement } \\
\text { costs }\end{array}$ & High & $\begin{array}{l}\text { - Performing } \\
\text { efficiency } \\
\text { - Transferring risk } \\
\text { to the insurance } \\
\text { company }\end{array}$ \\
\hline $\mathrm{R} 24$ & $\begin{array}{l}\text { Increase in } \\
\text { building } \\
\text { materials } \\
\text { prices }\end{array}$ & Extreme & $\begin{array}{l}\text { - Price adjustments } \\
\text { based on the } \\
\text { articles } \\
\text { contained in } \\
\text { thecontract and } \\
\text { price } \\
\text { negotiations with } \\
\text { owner. } \\
\text {-Purchasing of } \\
\text { material at the } \\
\text { beginning } \\
\text { via bank payment }\end{array}$ \\
\hline
\end{tabular}

Table 12 shows mitigation measures which could be done for risk priority which have been found and figure 2 shows the risk is spread in two risk treatment areas, 
namely detect and monitor and prevent at source. The risks in the detect and monitor area consist of the risk of mistaken translating DED to shop drawing (R06) and the risk of quality of goods and services produced by the vendor does not meet the specifications agreed upon in the contract (R09).

\section{Summary}

From the risk analysis which have been done on Andalas University Hospital project, the follows could be summarized :

1. There are four types of risks identified in accordance with the project organization structure of PT. Adhi Karya Tbk were engineering, production, construction and financial risks with total risk variable are 24 items.

2. It was obtained 5 (five) priority of risk variables with highest weight for each risk type, there is: (a) mistaken translating DED to shop drawing. (b) quality of goods and services produced byvendors not meet the specifications. (c) accident in the project area (d) additional procurement costs. (e) increase in building materials prices.

3. The most influential risk categories are as follows: (a) extreme, which is the risk of increase in building material prices with risk level value is 20. (b) high, namely the risk of additional procurement costswith risk level value is 12 . (c) medium, are the risk of accident in the project area, mistaken translating DED to shop drawing, and the quality of the goods and services produced by the vendor does meet the specifications.

\section{References}

1. A. Sandyavitri, Risk Management in Construction Project, Media Komunikasi Teknik Sipil, Jurusan Teknik Sipil Fakultas Teknik Universitas Riau. (in Bahasa) (2009)

2. T. Kurniawan, Enviromental Risk Assessment using Analytical Hierarchy Process Approach and Risk Management ISO 31000 (Case study : Waste water Treatment Installation of RSUP Dr. Djamil Padang), Final Project, Industrial Engineering Department, Engineering Faculty Andalas University, Padang. (in Bahasa) (2013)

3. I. Ismael, Building Project Delay, Cause and Its mitigation, Jurnal Momentum. 1 (14), 47-48. (2013)

4. I.W. Ervianto, Construction Project Management, (Andi Offset, Yogyakarta,, 2005)

5. Efrizon, Risk Management Study using Risk Breakdown Structure Approach and Analytical Hierarchy Process (Case Study : Jalan Manggopoh-Padang Sawah Simpang Empat Project). Thesis, Teknik Manajemen Konstruksi Universitas Bung Hatta. Padang. (in Bahasa), (2014)

6. L.J. Susilo, V.R. Kaho, Risk Management based on ISO 31000 for Non-bank industrial, (PPM Manajemen, Jakarta, 2011)

7. T.L. Saaty, The Analytic Hierarchy Process for Decisions in a Complex World, New York. Pittsburgh, University of Pittsburgh, (2012)

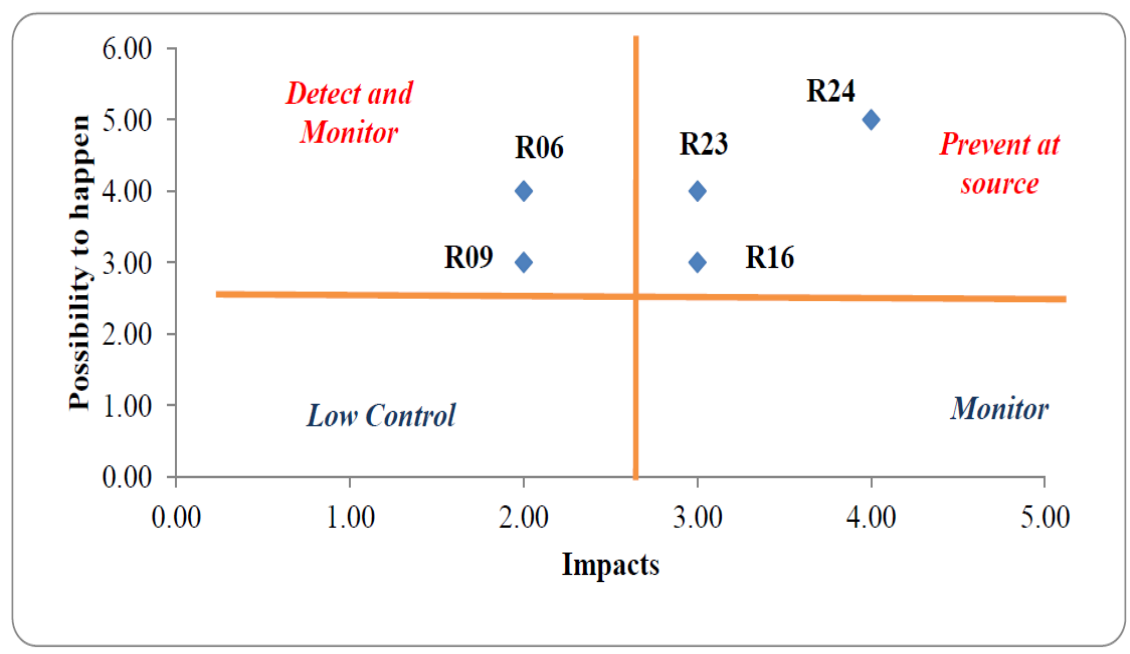

Fig. 2. Risk treatment map of each risk priority 